\title{
Feeding Anti-Semitism: Representations of Jewish Food Practices in Der ewige Jude
}

Forrest Picher*

Department of History, McGill University, Montreal, QC forrestpicher@gmail.com*

\begin{abstract}
The film Der ewige Jude has received a considerable amount of scholarship, but never solely in the context of its representations of Jewish food practices. This paper addresses this void arguing that the representations are used to de-civilize and dehumanize the Jewish people in the minds of the viewers. The representation of Jewish home life around the dinner table is done in such a way as to emphasize filth and bugs. Similarly the conditions of street food are naturalized and used as "evidence" that the Jewish people are a lower race. Later, as the film describes Jewish cultural practices it completely subverts the meaning of Purim in such a way as to access the longstanding prejudices of Jews as "bloodsuckers". Finally, kosher slaughter is used to separate Jewish people from both a sense of Germanness and a European identity altogether. In fact, I argue this representation served as an argument to deny European Jews their humanity altogether. In all of these ways the film creates a cinematic argument that attempts to jus tify what would become the mass-murder and genocide of the European Jews.
\end{abstract}

\section{KEYWORDS}

Food; Film; Representations; Ghetto; Purim; Kosher

\section{INTRODUCTION}

With the invasion of Poland in 1939, the National Socialist government increased the number of Jewish people under its control from 300,000 to two million. ${ }^{1}$ In response, the freshly appointed head of the Ministry of Propaganda's Film Department, Franz Hippler, was sent to the Jewish Ghettos in October of 1939 to create a "documentary" about the so-called "Jewish problem". The footage was compiled and spliced with fictional movies, newsreels and footage of an Adolph Hitler speech. On November 28th 1940, the film titled Der ewige Jude (The Eternal Jew) was premiered. After its release and throughout the war, the film served as a, "cinematic argument that legitimated the approaching Holocaust". The first transportations of German Jews to the East began immediately after the film's release. ${ }^{2}$

First, it will be important to explain why I have focused on this particular film. I chose to study Der ewige Jude for two reasons. The first reason is that the film tries hard to appear ethnographic. Indeed, the film frames itself as a "study," projecting a sense of scientific authority that would have given the film's representations more weight to the public than other, similar films.

Furthermore, because this was likely the first that everyday Germans would have witnessed of Jewish communities in Poland, the film's seemingly authoritative representations would have likely seemed "authentic" to the German public. The second reason for choosing this film is its time and location. Der ewige Jude, as I will argue later, provides footage of the immediate aftermath of the German Blitykrieg invasion of Poland. Because of this, the film offers a unique vantage point for studying the effects of Blitzkrieg and the German occupation on Jewish practices. In addition, as I will argue later, the film offers a window into the way that the Nazi propaganda machine was able to create a positive feedback loop manipulating this Blitzkrieg destruction in order to create an argument for further destruction.

I argue that the film's representations of Jewish food and drink were mobilized to dehumanize the Jewish people, creating a culinary legitimation of the Holocaust. I will begin by analyzing the film's representation of food sale and consumption on the streets in the "ghettoes", deconstructing its argument of authenticity and addressing the ways the activity was used to dehumanize the Jews through direct comparisons to rats. I will then analyze the film's representations of Jewish Purim, particularly focusing on the representations of wine. I will argue that the film contextualizes the drinking of wine as "commemorat[ing] a slaughter" and was meant to refer directly to prejudiced conceptions of "the bloodthirsty Jew." In doing so, the representations of wine were meant to Other the Jewish and incite fear of them in ways that would legitimize their destruction. Finally, I will discuss the very graphic representations of kosher slaughter practices. I argue that these representations were a way to dehumanize the Jews to the German public, as well as to legitimize the Holocaust. By contrasting the "senseless brutality" of kosher slaughter with the humaneness of modern mechanized slaughter, aspects of which would later be used during the mass murder of European Jews, the film becomes both an argument for dehumanization as well as an argument for the mechanics of the Final Solution. 
While the film has not specifically been analyzed in terms of food representations, it has received significant scholarly attention. Rolf Giesen's seminal book Nazi Propaganda Films presents Der ewige Jude, and comparable films, as propaganda that sought to justify that Jews were "Untermenschen, undermen or subhuman specimens." Susan Tegel expands this idea in her book Nazis and the Cinema. She argues that this idea of inferiority was manifested in the film's representations of Jews' supposed inability to work the German way. Tegel argues that the film maintains Jews "rarely engage in useful work", showing footage of Polish Jews inefficiently clearing rubble from the streets. These images are later contrasted with the competency of the so-called German "Aryan" race. While in reality this particular representation is a testament to the forced labour of people who were not used to physical labour (middle class professionals according to Tegel), it is presented as an innate inability in the Jews themselves. According to the film, Jews are a lower, less-capable people. ${ }^{4}$ My analysis will build on these ideas. I argue that the film sought to dehumanize the Jews, using food practices to represent them as a race of Untermenschen in order to justify their removal from German society and legitimize the Holocaust.

In her chapter "A Cinematic Construction of Nazi Anti-Semitism", Joan Clinefelter argues that the film was both proof of the existence of the "Jewish problem" and an argument for its solution through the Holocaust. In making this argument, Clinefelter proposes that Der ewige Jude "constructs an illusory world" that sought to legitimate the Nazi party's perverse ideas in the minds of the German people. ${ }^{2}$ Hilmar Hoffman constructs a similar argument in his book, The Triumph of Propaganda. Hoffman argues that films such as Der ewige Jude sought "to justify in advance the mass murder of the European Jews." ${ }^{2}$ My argument in this paper will follow a similar interpretation, although taking it a step further. My analysis will anticipate the Final Solution in order to understand the true impact of the film and to contextualize the arguments made within it, while simultaneously understanding the Polish invasion and the film itself as part of the Holocaust.

In writing this article then, I am situating my argument within a recent trend of writing about the Holocaust that rejects the need to find the exact date at which the mass murder of Jewish people was decided by the Nazi leadership. Increasingly, many historians question whether there even was a single decision. Instead, recent scholarship has focused on a longer-term perspective that includes the initial invasion of Poland and Kristallnacht as part of the Holocaust. In his seminal book Histories of the Holocaust, Dan Stone writes that more and more, "historians' fixation on the timing of the Final Solution seems less important than explaining the steady and (with hindsight) seemingly unstoppable drift towards full-scale mass murder." The scholar continues, arguing "in terms of understanding how the Holocaust could happen, the paradigm turns to some extent away from a legalistic one of the search for incrimination documents and to a more anthropological one, which stresses the culture of racial fantasies that drove the Nazi regime." 6 This understanding will be fundamental to my approach. I am not seeking to pinpoint an exact moment when the Holocaust began. I am instead writing from this more anthropological perspective that sees Der ewige Jude as part of a development that led to mass murder. The implicit assumption within this argument is that the Holocaust began much earlier than the 1942 Wannsee Conference. To do otherwise would be to exclude the Jews murdered during the invasion and occupation of Poland, and those who starved in the Ghettoes, from the category of Holocaust victims. This would be untrue which to this author is unacceptable. Most of the people represented in a prejudiced manner in the film were later killed in the ghettoes, by starvation, or in death camps. Haunting the film is the fact that, for example, of the 230,000 Jew that lived in Łódź (one of the film's locations), only 877 remained alive when the Soviet army reached the city on January 19, 1945.7 In this way then, while my discussion anticipates what would become the mass murder of European Jews, it is also describing a part of the Holocaust that we as historians are increasingly coming to understand.

\section{FOOD AND THE “GHETTO”}

From the beginning of the film, the viewer is confronted with the frightful conditions of Jewish life in post-Blitzkrieg Poland. While largely a product of the German invasion and occupation, the film naturalizes these conditions as authentically Jewish, stating that these are "actual shots of the Polish ghettos" and that these Jews "have [not] suffered from the chaos of war as has the native Pole." "8 Hippler promoted the film as unbiased, as well. In an interview in the German magazine Judenfrage, he stated, "we let the filmed Jews be on their own and tried to shoot in moments when they were unaware of the camera's presence. Consequently we have rendered the ghetto Jews in an unprejudiced manner, real to life as they live and react in their own surroundings." Hippler's statements then corroborate the film in arguing that the conditions captured by the film were none other than the uninterrupted, natural conditions of the Polish Jews. Thus, from the very beginning, the viewer is expected to understand the footage as an unbiased documentary of a supposed race of Untermenschen. It is in this context that food is first mentioned.

The first representation of food in the film is footage of a family eating a meal in a run-down apartment. Nine people are shown cramped around a dinner table as a man approaches from off-scene carrying a bowl of bread. Immediately, all of the diners erupt into greedy fits, reaching for morsels of bread. The narrator simply notes, "Jewish home life reveals a remarkable lack of creative ability to civilize." 8 The viewer is therefore presented with the argument that this level of food-etiquette is demonstrative of the level of a people's civility. This emphasis is likely engaging with other German writing on civilization and food during this period, 
most notably with that of Norbert Elias. In 1939 Elias published his famous book The Civilizing Process in Basel, Germany. Andrew Linklater and Stephen Mennel write that this book was written "to explain how Europeans came to think of themselves as more 'civilized' than their forebears and neighboring societies."10 These "neighboring societies" could also include the Jews who had lived in communities alongside Christian communities in Europe for hundreds of years. This would help to explain this emphasis on a "lack of creative ability to civilize". By contrasting the Jewish experience to rising ideas of European civility, this (likely staged) meal is intended to begin a process of what I will call "de-civilization"11. The film then shows footage of what appears to be cockroaches collected on a wall (although it is unclear whether this is the wall of the original house or not), and then quickly cuts back to the dinner table. "In plain language," the narrator continues, "Jewish dwellings are filthy and neglected." 8 In this way, filth and bugs are presented as the types of things one would find surrounding the supposedly uncivilized eater, adding to the decivilization. In presenting this footage in this way the film is arguing that not only do the Jews lack food etiquette, they lack basic food hygiene. Because these conditions presented around food are repeatedly described as authentic, the viewer is led to believe that Jews are an uncivilized people. This is the first of a long series of efforts to dehumanize the Jewish people.

As the film moves out of the home and into the streets of the supposedly authentic ghetto, food is everywhere. People are selling and buying food, and young Jewish children, weaving through the crowd, find solace on a doorstep for a quick snack. The foods bought and sold range anywhere from live ducks to hanging meats to potatoes to prepared snacks on trays - all, of course, sold on the street. Every aspect of this is naturalized in the film's representation. Even the poor children selling food are deemed authentic: "One might want to regard these haggling children as a sign of great poverty" the narrator begins. "But watch them a while and it becomes clear that they are proud to act as their grownups do." 8 In this way, the film argues that the crowded streets are characteristic of the people, and any appearance of poverty among the sellers of food is not true poverty, but a realization of a supposedly Jewish nature.

This supposed authenticity of filthiness surrounding eating in the home, coupled with the naturalization of crowding activity surrounding the sale and consumption of food is essential for the film to make a direct comparison between Jews and the rat. The footage of Jews moving through the busy streets rife with food is juxtaposed with footage of rats running in packs through food stockpiles. Similarly, the footage of Jews selling and purchasing food and Jewish children eating on the steps of homes is juxtaposed with rats infiltrating grain stores. In these ways, the crowded conditions around Jewish food consumption of the early occupation period were used to make comparisons between the Jews and rats. In doing so, the film sought to further dehumanize the Jews.

These associations are not left solely to the interpretation of the viewer. Instead, the film attempts to make this comparison as explicit as possible. When discussing the Jewish "wanderings throughout the world" the narrator argues it is "parallel" to that of "a similarly restless animal: the rat." " Later, when discussing rats, the film states that, "They are cunning and cruel and usually appear in massive hoards... just as the Jews do among mankind." 8 Thus, the conditions in which a significant amount of food is exchanged and consumed are represented in a context of dehumanization. The heavily populated streets are used to represent the "massive hoards" of the Jews presented as a threat to Germany, much like rats were presented as a threat to her food. In doing this, the film is creating a cinematic argument for a "Jewish problem" - one that would require a solution.

The comparison between Jews and rats through the nexus of food was one aspect of the film that appears to have greatly impacted its audience. In an analysis of the film's reception, Terry Charman writes that a report from the Sichersheitsdienst noted that "the comparison with rats is mentioned as particularly impressive."12 The comparison to rats was also mentioned in the Nazi newspaper Deutsche Allgemeine Zeitung which commented favourably on the comparison between Jewish migrations and rat migrations. ${ }^{13}$ In a local German paper on the Dutch border, Moers, the comparison was lauded. The paper wrote that the representation would "clarify to the very last Germans that the Jews as a race is, and will forever remain, beneath human kind, as the rats are beneath the animals: parasites, poison carriers and subversive scroungers." 14 We can therefore see that not only did these food representations seek to dehumanize Jews through the comparisons to rats, but that these appear to have been at least somewhat successful.

Much as rats are a plague that needs to be eliminated for the health of a country's cities, the film argues that Jews, described as a plague at the beginning of the film, need to be eliminated. From the very beginning then, these representations of food corroborate Hoffman's interpretation of the film as "justify[ing] in advance the mass murder of the European Jews." In addressing the legacy of these representations as arguments for the legitimization of the Holocaust it becomes essential to show that these supposed "authentic" food practices are not actually authentic. Instead, they must be seen as the result of ghettoization policies and the destruction of Blitzkerieg warfare.

While all scholars agree that the film is not representing authentic conditions, there is substantial debate about what specifically created them. Particularly, the role of Nazi policies of ghettoization remains controversial. Some have argued that the film was 
shot after ghettoization had already been enforced. Susan Tegel, for example, wrote that Der ewrige Jude was filmed in "the newly created ghetto in Lódź."15 Tegel went on to argue that while the film represents the conditions as authentic, "at that point life was anything but ordinary for Polish Jews". The scholar concluded that we should interpret "[this] extraordinariness [as] a consequence of German policy." establishment of ghettos start[ed] in the same autumn of 1939."'17 This is an early theory of the emergence of the ghettos. Indeed, Tegel and Rozett's arguments rely on the assumption that ghettoization began immediately after the German occupation of Poland. The German invasion began on September $1^{\text {st }} 1939$, and one month later, filming had begun. ${ }^{18}$ According to Tegel and Rozett then, Jews were immediately ghettoized. Christopher R. Browning, however, argues for a later origin of ghettoization policies, beginning in Warthegau in the spring of $1940 . .^{19}$ According to Browning, these policies of ghettoization would have occurred after the filming of Der ewige Jude in Poland was finished.

The reality however was likely a mix of both of these interpretations. Ghettoes existed before the German invasion of Poland. ${ }^{19}$ Furthermore, it does not appear that the Germans had actually begun enforcing the sort of ghettoization necessary for Tegel and Rozett's argument immediately after the invasion. In a thorough analysis of communications between officers during the early German occupation of Poland, Dan Michman argues that the Jews were not being forced into ghettos. ${ }^{19}$ While it is true that Germans had demarcated the boundaries of these existing ghettos and "forced those Jews who had moved elsewhere in the city to return "home," 20 the full sealing of the ghettos that would come to characterize the experience of Jewish Poles did not begin in Łowicz until May 1940 and would not impact Warsaw until November of that year. ${ }^{21}$ While certain aspects of ghettoization must be included in the debate, the conditions were not entirely a result German policy.

Oddly, while much debate centres on ghettoization, there is little said about the bombing of Polish cities during the Blitrkerieg. After the Luftwaffe destroyed most of the Polish air force, it focused on bombing the cities. ${ }^{22}$ Warsaw, "the chief bastion of Polish defiance," was particularly hit hard. ${ }^{23}$ On September 20th 1939 , the Luftwaffe launched a colossal attack on the city, involving 620 aircrafts. The next day, these massive air attacks continued, with the Luftwaffe bringing in " 52 transport planes to drop incendiaries." 23 By the time Warsaw surrendered, it had incurred massive destruction. One study states that up to 40 per cent of buildings in Warsaw were severely damaged, and 10 per cent were destroyed entirely. ${ }^{24}$ This destruction would have put pressure on non-damaged buildings, leading in part to the crowded conditions of the ghetto. Indeed it is possible that the family of ten in the dinner scene could be a family hosting its relatives that had moved out of their damaged homes. In this way, the homes and street conditions surrounding eating in the beginning of the film are not representative of authentic conditions, but should be contextualized within intensively bombed cities. The degree to which this bombing was responsible for crowding is a topic that needs further research.

In addition, during the invasion of Poland the Nazi forces specifically targeted centres of Jewish community life. Jewish shops were attacked and destroyed and many synagogues that served as Jewish meeting places and community centres were razed. ${ }^{25}$ Thus, it is possible that the crowded streets full of salesmen and saleswomen selling food are a result of the destruction of Jewish shops by the German army and SS. Furthermore, the crowded nature surrounding this street food could be seen as representing a new centre of community life. It is possible that at the time of the film these crowded streets stood in for the Synagogues as centres of Jewish community after the latter's destruction by the German forces. The film therefore naturalizes conditions brought about by the German invasion and occupation of Poland as authentically Jewish in order to legitimize the further destruction of Jewish life. These two issues should be essential to historians in their interpretations of the film and deserve more attention in the future.

\section{PURIM AND BLOOD}

The film then discusses Jewish cultural practices with a particular focus on Purim. Purim is represented with the explicit intention of de-civilizing and dehumanizing the Jewish people in order to make a cinematographic argument for their mass murder. To make this argument, the film focuses on the imagery of wine drinking to access German folklore and stereotypes about the mythical Jew as a bloodsucker.

In framing this discussion it will be important to first establish what Purim is. Of course, Judaism is a very rich and diverse religion, and Purim is not celebrated the same way in every community. What I will describe then will not be true for all forms. Instead, I will focus in on the Eastern European Hasidic tradition, as that is most comparable to what is being represented in the film. According to Daniel Boyarin, there are two distinct forms of celebration: the high and the low. The high practice involves public readings of the Book of Esther, the story that Purim celebrates. ${ }^{26}$ The low practices, that will be the focus of this paper, are not as entrenched in the Tanakh as the high practice. Instead, these low practices are "explicitly prescribed in the balakic literature or by custom."26 According to Boyarin, these low practices include "public drunkenness, treated by the Talmud as an obligation." ${ }^{26}$ On many levels this drinking was an important engagement with the story of Esther. In her seminal article, "The 'Drinking 
Banquet' (Trink-Siyde)", Shifra Epstein writes, "drinking on Purim is necessary to fulfill the precept that one drink until one can no longer distinguish 'Blessed be Mordecai'... from 'Cursed be Haman." 27 In this way, the drinking on Purim is a direct engagement with the story. By engaging with this story, Jewish participants are celebrating a narrative of what Boyarin calls a "resistance through accommodation" in which Mordecai and Esther were able to overcome Haman's intended destruction of the Jewish population from a position of weakness. ${ }^{28}$

The film attempts to actively misrepresent this practice. As Purim is introduced, the narrator states that, "This harmless looking family celebration commemorates the slaughter of 75,000 anti-Semitic Persians by biblical ancestors of our Jews of today." 8 In this very swift distortion, the film decontextualizes the feasting and drinking, changing it from an engagement with a story of preservation to a celebration of murder. By centring the celebration on murder, the film lays the groundwork for the ways that the representations of food and drink, particularly wine, will reflect German folkloric conceptions of the Jew as a murderer and bloodsucker.

First, the Nazi's perverse interpretation of Purim as a celebration of murder is interpreted in the film as a product of Jewish character. "That's the race of Israel" the narrator starts, "still rubbing its hands over its feast of revenge." In this way, the film is making an argument to the viewer that this supposed celebration of murder is indicative of a perverse race, a murderous Untermenschen. In doing so, the film again seeks to de-civilize and dehumanize the Jew. The narrator continues stating that modern Jews "dressed in the Western European clothes" were trying to "hide their murderous nature." ${ }^{8}$ Much like the comparison of the Jew to the rat, the film begins with allusions and then explicitly states its intent. Here, the Nazi interpretation of Purim is explicitly presented as indicative of a murderous nature within Jewish character itself.

This supposedly murderous character is then linked to the prejudiced conception of Jews as blood drinkers. Immediately after drawing attention to the so-called "murderous nature" of the Jews, the film shows a Jewish man pouring himself a glass of red wine and drinking it. This representation alludes not only to fears and prejudice of Jews as murderers but also to ideas about Jewish vampirism. Tegel argued that the term "bloodsucker" was a frequent slur used against Jews during this period in Germany. ${ }^{29}$ Jamil Khader would agree. In his article "Humanizing the Nazi?" Khader writes, "The trope of the Jew as a vampire, the blood-sucking Nosferatu, occupied a central position in the anti-Semitic Nazi racial ideology." 30 By bringing in a connection to Nosferatu, the 1922 German silent film adaptation of Bram Stoker's Dracula, Khader touches on an important point of analysis that needs to be developed further. There are, for example, many aspects of the Nosferatu narrative that are accessed in Der emige Jude to prime the audience to view the wine drinking as blood drinking.

First, the physical features of the Jews in caricatures promoting Der emige Jude (Figure 1) relied on stereotypical features such as large hooked noses, sunken black-ringed eyes and large pointed ears. These stereotyped caricatures are very similar to the representation of Nosferatu in the vampire film (Figures 2 and 3). By presenting a very similar image, the film intended to draw some of the expectations of the Nosferatu narrative in order to represent the Jews as vampires.

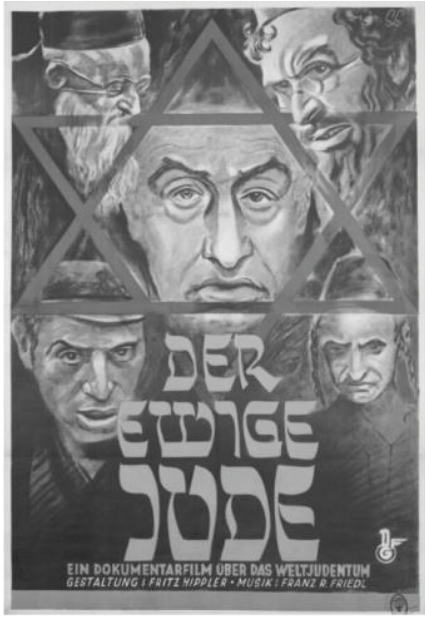

Figure 1: Der enige Jude poster

"Der Ewige Jude [The Eternal Jew]", Collection of the Imperial War Museum PST 8237. Reprinted with permission of the Imperial War Museum. 


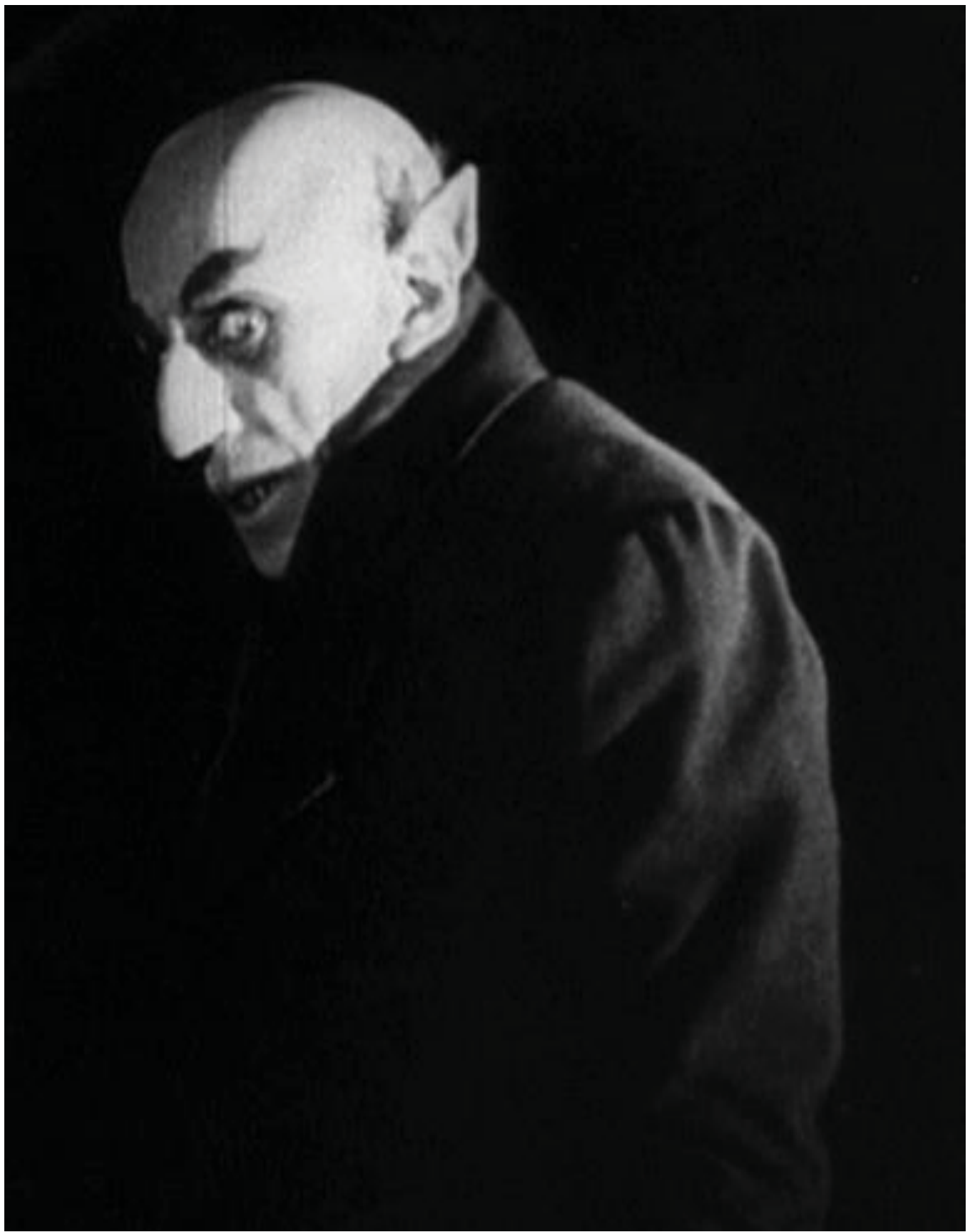

Figure 2: Nosferatu

Nosferatu: A Symphony of Horror, (1922) DVD, directed by F. W. Murnau, Image Entertainment, Chatsworth, CA. 


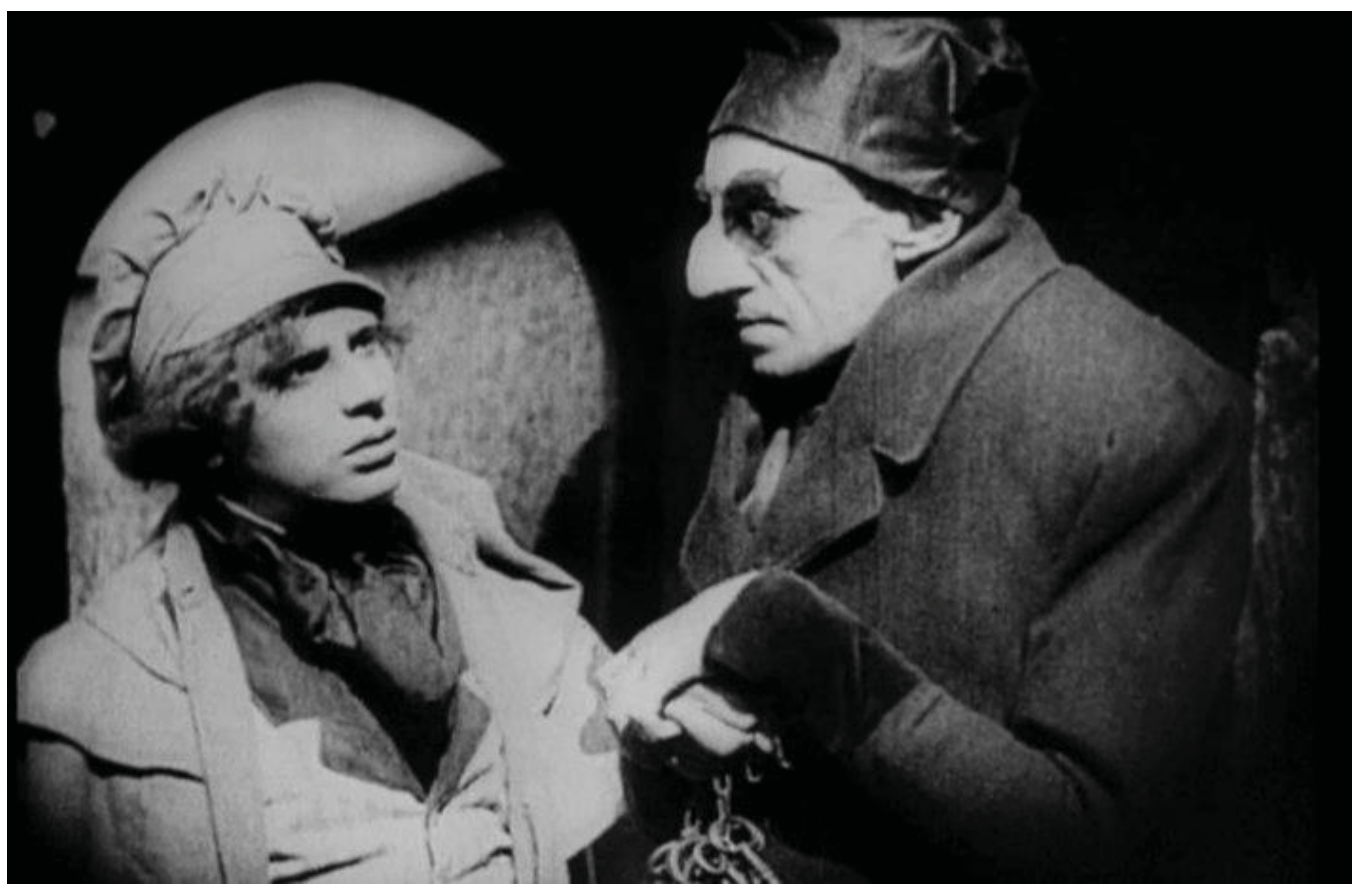

Figure 3: Nosferatu Nosferatu: A Symphony of Horror, (1922) DVD, directed by F. W. Murnau, Image Entertainment, Chatsworth, CA.

The second representation that anticipates the blood-drinking stereotype was the association of Jews with rats. Der ewige Jude makes direct comparisons between Jews and rats. This emphasis on the Jews as rats connects Jews to the vampire Nosferatu. In the film, Count Orlok (Nosferatu) is shipped from Transylvania to Wisborg, Germany. Alongside the coffin containing himself, Count Orlok ships coffins carrying hoards of rats. These rats, infested with the plague, cause disease in the town and leads to the death of many of Wisborg's residents. ${ }^{31}$ In addition, while rats bring the plague to Wisborg in Nosferatu, Der ewige Jude describes the Jews themselves as a "plague" drawing further associations.

By the time the film portrays the wine drinking, the viewer has already been primed with allusions to the Nosferatu vampire film and would be more likely to interpret the wine as blood, fuelling the already prominent prejudice promoted by the National Socialists of Jews as "bloodsuckers". By alluding to the Jews as bloodsuckers, the film tries to completely deny the humanity of Jewish people. Rather than being human beings, Jews become a monstrous race of inhuman evil vampires, leading to a justification for their mass murder. Again, the representation of food is used as a cinematographic argument for the Holocaust.

\section{KOSHER SLAUGHTER, BLOOD, AND THE JEWISH VAMPIRE}

The last section of the film is a representation of Jewish Kosher slaughter, a practice known as shehitah. According to Dayan L. Grunfeld's seminal work The Jewish Dietary Laws, the act of shehitah is a form of slaughter in which the shohet (a pious, learned person who has been trained according to Jewish law ${ }^{32}$ ) makes a "horizontal cut across the windpipe and gullet of the animal by means of a faultless and movable cutting instrument in a manner which is designed to secure a quick and painless death as well as the fullest draining of blood." 33 Indeed, this last point, the necessity of a full draining of blood, indicates an incredible irony in the film. While the Nazis represented the Jews as bloodsuckers comparable to Nosferatu, the consumption of blood in Judaism is Trefah (unfit for consumption according to Jewish dietary laws). ${ }^{34}$ This slaughter practice was therefore a way to drain the animal of blood for the very purpose of not consuming the blood.

However, as with the other food practices, Der enige Jude represents the kosher slaughter in an incredibly distorted way. The film introduces the practice with a written warning:

One of the most illuminating customs of the Jews' so-called religion is the slaughter of animals. The following actual scenes are among the most horrifying ever captured. We show them despite objections about poor taste. It's more important that our people know the truth about Jewry. Sensitive citizens are advised not to watch.

The first thing that needs to be unpacked is the representation of this slaughter as an "illuminating custom." The viewer is being primed to interpret the slaughter in much the same way as the other food practices are intended to be interpreted: as evidence that the Jewish people are degenerate Untermenschen. Indeed, much like the crowded streets and the comparisons to rats, the slaughter is meant to de-civilize and dehumanize Jewish people in the eyes of the viewer. The narrator questions the humanity of the 
practice stating that "[the Jews] let the animals bleed to death while conscious." He continues saying, "The Jews deceptively describe this cruel method as the most humane way to slaughter." 8 Because this representation is supposedly illuminating about Jewish character, and is obviously being represented as inhumane, the film is arguing that the Jews themselves are inhumane. A similar dehumanization is reflected in the reactions to the scene. In a summary of the film, the Nazi newspaper Deutsche Allgemeine Zeitung wrote that "The most frightful chapter comes at the end: the cruel, inhuman, barbarous slaughter of animals." 35 Here we can see a similar emphasis: the practice is seen as a reflection of a barbarous nature inherent in the Jewish people and is seen as so cruel as to deny their very humanity. This is a very disingenuous representation of the practice however, which is actually intended as a fairly humane form of slaughter. Indeed, in the book Animals in the Third Reich, Boria Sax argues that while the animals don't lose consciousness instantaneously, this loss of consciousness "generally comes only after a lapse of a few seconds to a minute for most animals." 36

However, the representation of the very explicit and bloody nature of the deaths in the film is meant to obscure this quickness and humaneness. Sax argues this emphasis on the bloodiness of the practice was critical in kosher slaughter's interpretation by the Nazi regime. The author writes, "The enormous symbolic significance that the Nazis attached to blood made death by bleeding seem perverse." Sax continues, arguing that in the minds of Nazi ideologues this form of killing was worse than death because it first deprived the animal of "primeval vitality." 37 This sense of perversion was then packaged in the film as an inhumane and cruel practice, and presented to the viewer as such. In this way, bloodiness was used to silence and circumvent humaneness in order to present an image of the Jew as uncivilized and inhuman. ${ }^{38}$ In doing so, the film created an argument that such peoples had no place within supposedly civilized Europe and needed to be removed from it.

The film situates itself within a long and supposedly progressive history of opposition to this practice in order to further present the Jew as exogenous, both an outsider to European civilization, and more specifically an outsider to a general sense of Germanness. The narrator states, "European [my emphasis] science has long acknowledged the torturous character of this type of slaughter." The emphasis on what is projected as a unanimous opposition by European science presents an intentionally uneven representation of the actual debate. As Robin Judd argues in "The Politics of Beef", there were actually some animal protectionists that endorsed kosher butchering, "because they believed that it produced a healthier quality of meat or because they did not believe that religious particularities deserved punishment." 39 However, the emphasis on the so-called "science" is likely referring to the veterinary profession, which Boria Sax has argued was highly nationalistic and anti-Semitic much before the Nazis' rise to power. Indeed, Sax notes that in 1933 there were only two Jewish students of veterinary science in all of Germany. ${ }^{40}$ This highly anti-Semitic profession later became intimately tied to the National Socialist Party and was incorporated in many of the Nazi government's decisions concerning animals. The main advisor to Hitler on policy concerning animals was a veterinarian named Freidrich Weber who, Sax notes, "participated with Hitler in the aborted coup of 1923."41

The film goes on to state that "Jewish law has no love and respect for animals in the Germanic sense."8 In saying this, the film actively works to subvert the actual humane intentions of the slaughter in order to present the Jews as cruel and an outsider to ideas of Germanness. By not sharing a so-called "German" love for animals, the Jew becomes the Other. In this way, the representation of slaughter, much like the representations of the other food practices in the film, seeks to define the Jew as foreign and uses its representation of kosher slaughter in order to make this specific argument.

The representation of kosher slaughter was not only intended to represent the Jew as an outsider to the category of European, it was also intended to remove the Jew from the category of human being altogether. While the actual practice is intended to avoid the consumption of blood, it was imagined during this period as a way for Jews to have and to consume blood. Nowhere is this clearer than in a popular story by Hans-Peter Richter used as a piece of virulent Nazi propaganda:

[T] he Jewish priest approaches the cow and slowly lifts the knife of sacrifice. The animal feels threatened with death, it lows and seeks to break free, but the Jew knows no pity... The merciless Jew does nothing to shorten the suffering of the bloody animal; he wallows in it; he needs blood... ${ }^{37}$

In representing copious amounts of blood, the film was echoing this emphasis on a Jewish "need" for blood. In doing so, the representation of kosher butchering built on the idea of Jewish vampirism that occurs throughout the film. However, the association of kosher slaughter and blood drinking was not unique to Der ewige Jude but was occurring within a long history of debate within Germany. According to Robin Judd, many animal rights activists in the late $19^{\text {th }}$ and early $20^{\text {th }}$ centuries demanded that the newly established slaughterhouse commissions of the veterinarian profession create laws that forbid Jews from drinking the blood after kosher slaughter. ${ }^{34}$ There was therefore a long precedent associating this form of slaughter with blood drinking in the imaginations of the German people. By emphasizing this aspect, the film was accessing this widespread prejudice to further dehumanize the Jewish people. 
Furthermore, the film emphasizes the supposed torturous and cruel nature of the practice. The narrator states, "These [slaughters] ... also reveal the character of a race that hides its senseless brutality behind the façade of pious religious customs." 8 This idea of a "senseless brutality" as a Jewish characteristic was intended to speak to a long history of German prejudice that linked kosher slaughter to folklore of Jewish ritual murder. Judd explains that the late $19^{\text {th }}$ and early $20^{\text {th }}$ century debate on kosher butchering "consistently voiced concerns with the allegedly violent character of shehitah, thus implying that the Jews were themselves deviant and cruel." 42 By arguing that the supposedly cruel and torturous nature of the slaughter "reveal[s] the character of [the Jewish] race" the film is situating itself within an extensive literature on the subject of kosher slaughter that vilified Jewish people. In doing so, the film was also linking itself to some of the quite fanatical accusations within this literature, the most potent of which, Judd argues, was the link between kosher butchering and ritual murder. ${ }^{42}$ In the late $19^{\text {th }}$ century there were several cases in Germany in which the ability to perform kosher slaughter was actually used as evidence to prove the existence of ritual murder. For example, in 1892, there was a case in Rhineland in which a Jewish shobet was arrested for the murder of a child. According to Judd, the shohet had been suspected because "he was one of the few residents in Xanten [Rhineland] who would be capable of decapitating and bleeding a human, since he normally did so to cattle." 43 In the minds of many then these forms of slaughter would have alluded to ideas of the alleged Jewish practice in which Jews supposedly captured and killed Christian children in the Passover service. ${ }^{43}$ By portraying Jews as Christian murdering vampires, the film created an argument for the destruction of the European Jewry that would result in the mass-murder of Jewish people.

Similar allusions between kosher slaughter and ritual murder and blood drinking are seen in other propaganda sources of the time period. In May of 1934, for example, the German newspaper Der Stürmer released a special issue on "Ritualmord-Nummer", which translates to "Ritual Murder Issue." In this issue, the paper uses virulent hate speech intertwined with images that blatantly connect the practice of kosher slaughter with ritual murder myths. In Figure 4, for example, the newspaper shows a shochet with the traditional blade used in kosher slaughter standing under a group of children with cut throats. His Jewish helper is collecting the blood in a dish that features a subtle Star of David on the handle.

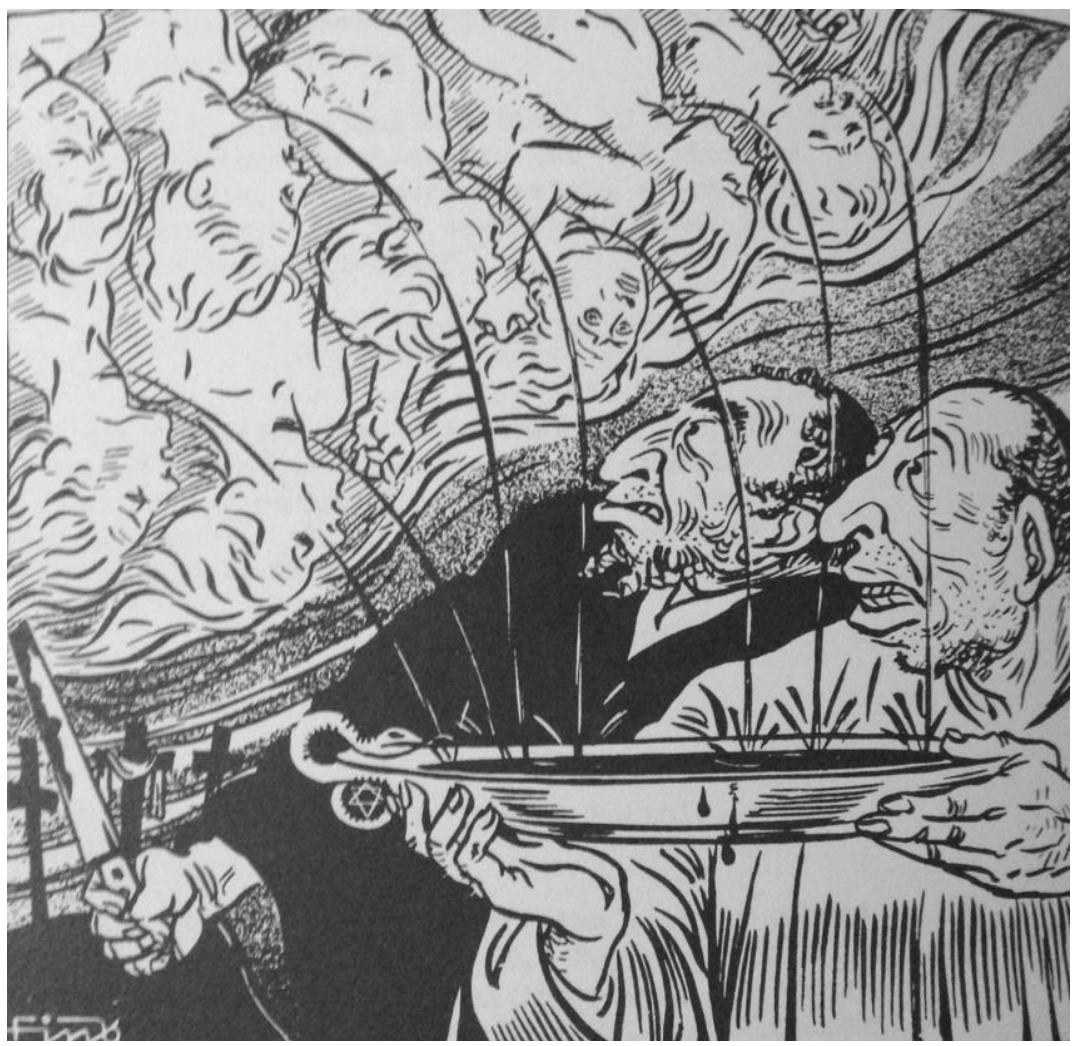

Figure 4: Caricature of Jews collecting the blood of ritually slaughtered children.

Source: "Ritualmord-Nummer" in Der Stürmer. May 1934.

In Figure 5, Jews in western dress are shown slitting someone's throat and holding him up, bleeding him into a bucket. The man cutting the throat is using a traditional blade for kosher slaughter. 


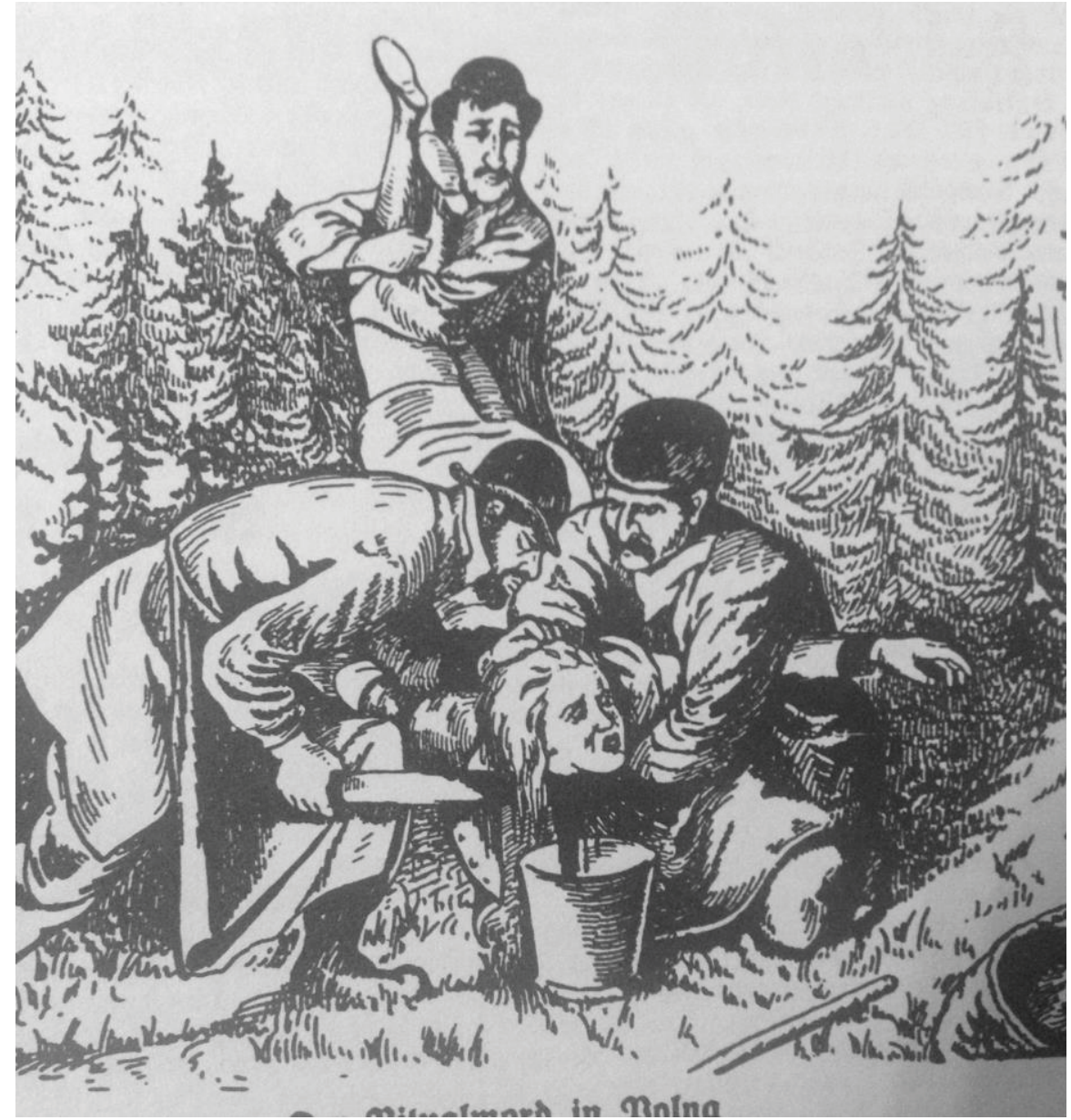

Figure 5: Caricature of Jews collecting the blood by ritually slaughtering a man.

Source: "Ritualmord-Nummer" in Der Stürmer. May 1934.

Finally, in Figure 6 we can see the most obvious allusion. A child is strewn naked across the table as four men wearing skullcaps drink the child's blood through straws. Thus, it becomes apparent that the connection between kosher slaughter and ritual murder and vampirism was established prior to the film's production. The film is therefore accessing a longstanding prejudice in order to further dehumanize the Jew in the mind of the viewer by calling to attention prejudices that the viewer was likely already aware of.

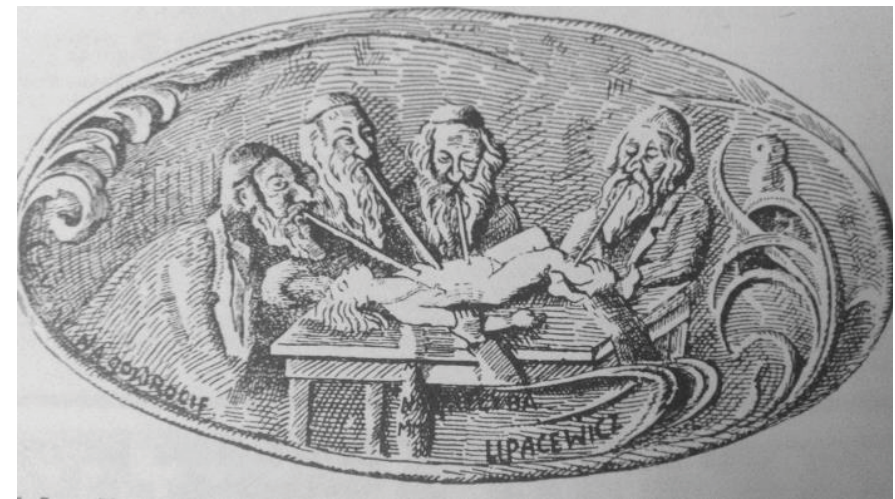

Figure 6: Caricature of Jews drinking the blood of a child. Source: "Ritualmord-Nummer" in Der Stürmer. May 1934. 


\section{KOSHER SLAUGHTER AND THE MECHANICS OF THE HOLOCAUST}

After this footage of the slaughter is shown the film presents the Nazi laws forbidding it in order to justify both the humanity of the Nazi party as well as their commitment to the welfare of animals. The narrator states, "Right after the Führer took power, a law enacted April 21, 1933 forbad the Jewish form of slaughter. It decreed that all warm-blooded animals be given anaesthetic before slaughter." In this way, the film presents the Nazi party as eliminating the Jewish practices with the modern industrial form of slaughter involving stunning the animal first. However, this does not stop at the elimination of Jewish practices. Instead, this should also be seen as an argument for the elimination of Jews themselves by this modern industrial form of slaughter in what would later devolve into mass murder. Both the infrastructure and ideas of these modern industrial slaughter practices were used in the mass murder of European Jews. As the war extended in the Eastern front, the Wehrmacht began stealing animals from the occupied territories and shipping them West for slaughter. Simultaneously, these same train lines and cattle cars were used to transport Jews to death camps. ${ }^{44}$ Boria Sax argues that the very organization of industrial slaughterhouses and death camps were similar, writing that they "were [both] organized as factories that produced not conventional goods but death." 45

In addition, the ideas and practices of death camps were grounded in the ideas and practices of modern industrial slaughterhouses. Sax argues that Heinrich Himmler, notorious for both founding the SS and overseeing Auschwitz, had originally been a chicken farmer. Sax writes, "Many of his ideas for [the] systematic ... slaughter of human beings were simply the extension of mechanized farming to people." 46 Furthermore, Sax argues that practices such as forcing the Jews about to be murdered to strip naked and huddle together in crowds "suggests a herd of cattle or sheep." 46 This was furthered by other practices such as Heinrich Himmler's ordering for dogs to be trained to herd prisoners like livestock. ${ }^{47}$ By creating a performance of a slaughterhouse, the people running the death camps were able to mentally dehumanize the Jews as if they were animals in a slaughterhouse, thus making them easier to murder. ${ }^{46}$ In this way then, the representations of kosher slaughter in Der ewige Jude, and the drawing attention to the destruction of these Jewish practices by their replacement with modern industrial slaughtering, must also be seen as an argument that sought to legitimize not only the destruction of these practices by modern industrial slaughtering, but also the human beings to whom they belonged.

\section{CONCLUSIONS AND LEGACIES}

In her article "A Cinematic Construction of Nazi Anti-Semitism", Joan Clinefelter writes, "each cinematic ingredient [of Der ewige Jude] is transformed into visual proof of the 'Jewish problem' and the necessity of the Nazi's solution." 48 I have constructed my analysis to further this argument into the film's discussions of food. Food representations, as an essential and pervasive ingredient of the film, should be seen in this way. At every step, Jewish food is twisted and manipulated to create an argument for the destruction of Jewish people. In these ways, the film should be seen as presenting a justification and legitimation of the Holocaust. Moreover, these representations of food may have also contributed to a solidification of the Final Solution they sought to justify. Many of the architects of the Holocaust watched the film and had very strong reactions to it. Joseph Goebbels watched the kosher slaughter footage filmed in Poland and wrote: "This Jewry must be annihilated." ${ }^{49}$ Susan Tegel recounts that the footage was later shown to "the vegetarian Hitler and others who were 'deeply shocked'."49

\section{REFERENCES}

1. Tegel, S. (2007) Nazis and the Cinema, pp. 151, Hambledon Continuum, New York.

2. Clinefelter, J. (2000) A Cinematic Construction of Nazi Anti-Semitism: The Documentary Der ewige Jude, in Cultural History through a National Socialist Lens: Essays on the Cinema of the Third Reich, (Reimer, R., ed) pp.149, Camden House, Rochester.

3. Giesen, R. (2003) Nazi Propaganda Films: A History and Filmography, pp. 138, McFarland \& Co., Jefferson, N.C.

4. Tegel, S. (2007) Nazis and the Cinema, pp. 156, Hambledon Continuum, New York.

5. Hoffmann, The Triumph of Propaganda: Film and National Socialism, 1933-1945, 173.

6. Stone, D. (2010) Histories of the Holocaust, pp. 68, Oxford University Press, Oxford.

7. Charman, T. (2005) Fritz Hippler's The Eternal Jew, in Holocaust and the Moving Image: Representations in Film and Television Since 1933, pp.91, Wallflower Press, London.

8. Der Ewige Jude: ein dokümentarischer Film (1940), DVD, directed by Fritz Hippler, International Historic Films, Chicago.

9. Die Judenfrage, 28 November 1940.

10. Linklater, A. and Mennel, S. (2010) Norbert Elias, The Civilizing Process: Sociogenetic and Psychogenetic Investigations - An Overview and Assessment, History and Theory 49.3, 384.

11. "De-civilization," as I will be using it, refers to a process whereby one group attempts to deconstruct and deny the civilization of another group. This is done by Othering the latter group by presenting them as a negation to the understanding of what civilization is to the former group. It is therefore a virulent offshoot of ethnocentrism.

12. Charman, T. (2005) Fritz Hippler's The Eternal Jew, in Holocaust and the Moving Image: Representations in Film and Television Since 1933, pp.86, Wallflower Press, London.

13. Charman, T. (2005) Fritz Hippler's The Eternal Jew, in Holocaust and the Moving Image: Representations in Film and Television Since 1933, pp.85, Wallflower Press, London. 
14. Quoted in Johnson, E. A. (1999) Nazi Terror: The Gestapo, Jews and Ordinary Germans, pp. 385, John Murray, London.

15. Tegel, S. (2007) Naris and the Cinema, pp. 152, Hambledon Continuum, New York.

16. Tegel, S. (2007) Nazis and the Cinema, pp. 155, Hambledon Continuum, New York.

17. Rozett, R. (2005) Approaching the Holocaust: Texts and Context, pp. 4, Vallentine Mitchell \& CO. LTD, London.

18. Etlin, R. A. (2002) Art, culture, and media under the Third Reich, pp. 148, University of Chicago Press, Chicago.

19. Michman, D. (2011) The Emergence of Jewish Ghettos During the Holocaust, pp. 71, Cambridge University Press, Cambridge.

20. Michman, D. (2011) The Emergence of Jewish Ghettos During the Holocaust, pp. 74-75, Cambridge University Press, Cambridge.

21. Michman, D. (2011) The Emergence of Jewish Ghettos During the Holocaust, pp. 82, Cambridge University Press, Cambridge.; Bartoszewski, W. (1987) The Warsaw Ghetto: A Christian's Testimony, pp. 7, Beacon Press, Boston

22. Beevor, A. (2012) The Second World War, pp. 29, Little, Brown and Company, New York.

23. Beevor, A. (2012) The Second World War, pp. 34, Little, Brown and Company, New York.

24. facultystaff.richmond.edu, Bombing of Warsaw, https:// facultystaff.richmond.edu/ $\sim_{\text {wgreen/ecdwarsaw.html (accessed }}$ Mar,2015)

25. Rossino, A. B. (2003) Hitler Strikes Poland: Blitzkrieg, Ideology, and Atrocity, pp. 90-91, The University Press of Kansas, Lawrence.

26. Boyarin, D. (1994) Introduction: Purim and the Cultural Poetics of Judaism - Theorizing Diaspora, Poetics Today, $15.1,3$.

27. Epstein, S. (1994) The 'Drinking Banquet; (Trink-Siyde): A Hasidic Event for Purim, Poetics Today, $15.1,142$.

28. Boyarin, D. (1994) Introduction: Purim and the Cultural Poetics of Judaism - Theorizing Diaspora, Poetics Today, $15.1,5$.

29. Tegel, S. (2007) Nazis and the Cinema, pp. 150, Hambledon Continuum, New York.

30. Khader, J. (2011) Humanizing the Nazi?: The Semiotics of Vampirism, Trauma, and Post-Holocaust Ethics in Louise Murphy's The True Story of Hansel and Gretel: A Novel of War and Survival, Children's Literature, 39.1, 136.

31. Nosferatu: A Symphony of Horror, (1922) DVD, directed by F. W. Murnau, Image Entertainment, Chatsworth, CA.

32. Grunfeld, D. I. (1972) The Jewish Dietary Laws, pp. 54, The Soncino Press, London.

33. Grunfeld, D. I. (1972) The Jewish Dietary Laws, pp. 57, The Soncino Press, London.

34. Judd, R. (2003) The Politics of Beef: Animal Advocacy and the Kosher Butchering Debates in Germany, Jewish Social Studies, 10.1, 126.

35. Quoted in Charman, T. (2005) Fritz Hippler's The Eternal Jew, in Holocaust and the Moving Image: Representations in Film and Television Since 1933, pp.85, Wallflower Press, London.

36. Sax, B. (2000) Animals in the Third Reich: Pets, Scapegoats, and the Holocaust, pp. 143, The Continuum International Publishing Group Inc, New York.

37. Sax, B. (2000) Animals in the Third Reich: Pets, Scapegoats, and the Holocaust, pp. 144, The Continuum International Publishing Group Inc, New York.

38. Trouillot, M. (1995) Silencing the Past: Power and the Production of History, pp. 26, Beacon Press, Boston.

39. Judd, R. (2003) The Politics of Beef: Animal Advocacy and the Kosher Butchering Debates in Germany, Jewish Social Studies, 10.1, 136.

40. Sax, B. (2000) Animals in the Third Reich: Pets, Scapegoats, and the Holocaust, pp. 145, The Continuum International Publishing Group Inc, New York.

41. Sax, B. (2000) Animals in the Third Reich: Pets, Scapegoats, and the Holocaust, pp. 146, The Continuum International Publishing Group Inc, New York.

42,42. Judd, R. (2003) The Politics of Beef: Animal Advocacy and the Kosher Butchering Debates in Germany, Jewish Social Studies, 10.1, 124.

43. Judd, R. (2003) The Politics of Beef: Animal Advocacy and the Kosher Butchering Debates in Germany, Jewish Social Studies, 10.1, 125.

44. Sax, B. (2000) Animals in the Third Reich: Pets, Scapegoats, and the Holocaust, pp. 147, The Continuum International Publishing Group Inc, New York.

45. Sax, B. (2000) Animals in the Third Reich: Pets, Scapegoats, and the Holocaust, pp. 148, The Continuum International Publishing Group Inc, New York.

46. Sax, B. (2000) Animals in the Third Reich: Pets, Scapegoats, and the Holocaust, pp. 150, The Continuum International Publishing Group Inc, New York.

47. Sax, B. (2000) Animals in the Third Reich: Pets, Scapegoats, and the Holocaust, pp. 86, The Continuum International Publishing Group Inc, New York.

48. Clinefelter, J. (2000) A Cinematic Construction of Nazi Anti-Semitism: The Documentary Der ewige Jude, in Cultural History through a National Socialist Lens: Essays on the Cinema of the Third Reich, (Reimer, R., ed) pp.134, Camden House, Rochester.

49. Tegel, S. (2007) Nazis and the Cinema, pp. 163, Hambledon Continuum, New York. 


\section{ABOUT THE STUDENT AUTHOR}

Forrest Picher is currently pursuing a Bachelor of Arts in honors history at McGill University in Montreal, Canada. His work on the history of sharks has emerged out of a research project in the history of science focusing on the interrelationship of nature and empire. His other work has also focused on environmental history including the relationship between flooding and structural violence in northern Indigenous communities in Canada and the historical interaction between snow and urban geography.

\section{PRESS SUMMARY}

Nazi representations of Jewish food played an integral role in the dehumanization of Jewish people during the Holocaust. This article analyzes one source of these representations: Der ewige Jude (The Eternal Jew). It finds that Jewish food practices are intentionally misrepresented to both naturalize the conditions of Eastern Jews in post-Blitzkrieg Poland as a matter of Jewish character and also to access existing prejudices about Jewish people such as the blood-libel myth. In doing so, representations of food in the film were a way to mobilize hatred and legitimize the Holocaust. 